\title{
PENGGUNAAN BUKU BERGAMBAR TENTANG CARA BETERNAK DOMBA UNTUK MENGEMBANGKAN KAPASITAS PETANI MISKIN DI DUA DESA TEPI HUTAN DI KECAMATAN UJUNG JAYA, KABUPATEN SUMEDANG, JAWA BARAT
}

\section{THE USE OF ILLUSTRATED SHEEP REARING HANDBOOK ON POOR FARMERS' CAPACITY BUILDING IN TWO NEAR FOREST VILLAGES IN UJUNG JAYA SUB- DISTRICT, DISTRICT OF SUMEDANG, WEST JAVA}

\author{
Amri Jahi
}

\begin{abstract}
Building the capacity of the poor farmers that were living in two near-forest villages in Ujung Jaya sub-district, District of Sumedang, West Java was one of the activities accomplished to help such farmers raise indigenous Garut sheep. These activities included on site farmer training, monthly farmer meeting, supervision and other backstopping supports. These support services were provided before and after the sheep provision to the cooperating farmers. In this training, copies of an illustrated sheep raising manual covering several aspects of sheep rearing from feeding to marketing were tested with the participating farmers and were later given to them as reading materials. In this conjunction, two farmer groups from Palasari and Sukamulya villages were involved in the training sessions. At the opening session, the two farmer groups were tested to determine their prior knowledge about sheep rearing. After the pretetst, all participating farmers were individually given a copy of the sheep raising manual and was asked to read the manual for about 25 minutes. Next, they were asked to close the books and were given posttests. The results pointed out that the participating farmers improved their knowledge about sheep raising, though statistically not significant. Other tests accomplished on the data obtained, showed that the participating farmers' education correlated positively with their knowledge gains regarding sheep raising; whereas their ages and number of years since graduation correlated negatively with their knowledge gains about sheep raising.
\end{abstract}

Key words: Ilustrated manual, sheep raising, capacity building, poor farmers, Garut sheep, near forest village

\section{Pendahuluan}

Mengembangkan kapasitas para petani miskin yang berdiam di dua desa tepi hutan, di Kecamatan Ujung Jaya, Kabupaten Sumedang merupakan aktivitas awal yang dilakukan oleh Tim Pengembangan Sistem Produksi Ruminansia Kecil yang berbasis di Kabupaten Majalengka.

Aktivitas ini merupakan perluasan dari aktivitas pengembangan sistem produksi ruminantsia kecil, yang telah dilakukan di
Kabupaten Majalengka sejak 1989 (Jahi, 1989). Hal ini mungkin karena ada sejumlah domba dari Kabupaten Majalengka yang dapat digulirkan kepada para petani di dua desa di Kecamatan Ujung Jaya, Kabupaten Sumedang itu. Kecamatan itu bertetangga dengan Kabupaten Majalengka. Keduanya dipisahkan oleh Sungai Cimanuk. Letak geografis yang dekat ini, memungkinkan pembinaan para petani di dua desa itu dilakukan oleh penyuluh dari Majalengka. 
Dua kelompok petani kecil dilibatkan dalam aktivitas pengembangan ternak ruminansia kecil berbasis masyarakat ini. Setiap kelompok petani, yang terdiri dari sepuluh orang, akan menerima sepuluh ekor domba dara, yang telah masak tubuh, dan seekor domba jantan yang juga telah masak tubuh dan subur.

Agar para petani itu dapat memelihara dan mengembangbiakkan domba-domba tersebut dengan baik, maka kapasitas mereka sebagai peternak domba perlu dikembangkan dulu. Ini dilakukan melalui pelatihan, bimbingan, dan backstopping di lapangan. Aktivitas ini sejalan dengan himbauan Community Development Resource Association (CDRA) (1995) yang mengingatkan para penyuluh atau badanbadan pembangunan lain agar bertindak lebih dari sekadar mengikuti ajaran Konfusius: "Give a man a fish, feed him for a day, teach him how to fish, feed him for a life time." CDRA menyarankan agar penyuluh dan badan-badan itu, di samping melatih orangorang miskin agar bisa berbuat lebih tepat, juga membantu mereka agar memiliki akses pada sumberdaya yang dibutuhkan, sehingga keterampilan baru itu berguna untuk memperbaiki produktivitas dan kualitas hidup mereka.

$$
\text { Lebih jauh CDRA }
$$
menyarankan agar badan-badan pembangunan itu mengembangkan dulu: (1) a conceptual framework tentang masyarakat dan realitas yang ada di sekitarnya, (2) rasa percaya diri untuk bekerja dengan masyarakat, mampu menimbulkan dampak positif pada masyarakat dan mau bertanggung jawab, (3) memiliki struktur organisasi yang jelas, dengan peranan dan fungsi yang jelas, jalur komunikasi dan akuntabilitas yang nyata, dan prosedur pembuatan keputusan yang transparan dan fungsional, (4) mampu melatih dan mengembangkan keterampilan, kemampuan dan kompetensi khalayak sasaran dengan baik, dan (5) memiliki cukup sumberdaya keuangan maupun material untuk membiayai dan memfasilitasi perubahan yang diinginkan.
Sejalan dengan saran CDRA itu, sebuah pelatihan dirancang untuk para petani tepi hutan itu. Pelatihan ini dilakukan pada 23 Maret 2003 di salah satu ruang serba guna di Desa Ujung Jaya. Penelitian ini dilakukan bersamaan dengan pelatihan itu. Secara umum, penelitian ini bertujuan untuk menentukan seberapa jauh para petani kerjasama itu dapat memahami isi buku pedoman beternak domba itu. Secara khusus, studi ini bertujuan untuk: (1) menentukan pengaruh buku bergambar itu pada pengetahuan petani tentang cara beternak domba, (2) menentukan pengaruh buku bergambar ini pada peningkatan pengetahuan kedua kelompok tani itu tentang cara beternak domba, dan (3) menentukan intensitas hubungan sejumlah atribut para petani itu dengan tambahan pengetahuan yang mereka peroleh.

\section{Materi dan Metoda}

$\underline{\text { Materi }}$

\section{Materi Penyuluhan}

Materi yang digunakan dalam penelitian ini ialah sebuah buku bergambar yang berjudul "Pedoman Beternak Domba" (Sri Roso Satmoko, 1991). Buku ini terdiri dari 61 halaman. Setiap halaman memiliki unsur gambar dan teks, yang akan membantu pembaca memahami subyek yang diungkapkan. Gambar-gambar itu dapat menimbulkan efek belajar, seperti daya tarik, rasa senang, pemusatan perhatian, dan pemahaman.

\section{Khalayak Sasaran}

Khalayak sasaran yang hendak dicapai dalam studi tentang penyuluhan ini ialah dua kelompok petani miskin, yang berdiam di dua desa tepi hutan di Kecamatan Ujung Jaya, Kabupaten Sumedang. Tabel 1 berikut ini menunjukkan besar kedua kelompok petani, yang terlibat dalam pendedahan buku pedoman beternak domba bergambar itu. 
Tabel 1. Besar Kelompok Petani Miskin Tepi Hutan yang Didedahkan Pada Buku Pedoman Bergambar tentang Cara Beternak Domba

\begin{tabular}{ccc}
\hline \hline Desa & Ukuran Kelompok & Persen \\
\hline \hline Palasari & 10 & 50 \\
Sukamulya & 10 & 50 \\
\hline \hline Jumlah & 20 & 100 \\
\hline \hline
\end{tabular}

Tabel 1 di atas menunjukkan bahwa besar kedua kelompok petani miskin tepi hutan dari dua desa di Kecamatan Ujung Jaya, Kabupaten Sumedang yang dilibatkan dalam penelitian ini sama, masing-masing terdiri dari sepuluh orang.

\section{$\underline{\text { Disain Penelitian }}$}

Disain dasar yang paling mendekati untuk pelaksanaan studi penyuluhan ini ialah salah satu dari tiga pre-experimental designs, yaitu, the One Group Pretest-Posttest Design (Campbell dan Stanley, 1966, h. 7-9). Dalam studi ini, disain ini diulang dua kali untuk meliput dua kelompok petani yang berdiam di dua desa itu. Menurut Campbell dan Stanley (1966, h. 7), disain ini masih banyak digunakan dalam penelitian pendidikan. Dalam studi ini ancaman pada validitas internal yang mungkin ditimbulkan oleh efek history dapat diatasi dengan jalan memberikan pretes, perlakuan dan postes dalam satu blok waktu. Waktu yang diperlukan untuk melaksanakan studi ini relatif singkat. Sehingga peluang timbulnya intervensi atau gangguan dari hal-hal yang tidak dapat dikendalikan di antara pretes dan postes dapat diminimalkan. Jadi, efek atau pengaruh pendedahan buku pedoman bergambar tentang cara beternak domba pada postes akan terjadi tanpa gangguan.

\section{Data dan Instrumentasi}

Tiga macam data yang diperlukan untuk mencapai tujuan penelitian ini ialah data atribut para petani, pretes dan postes.
Untuk mengumpulkan ketiga macam data itu, dibuatlah sebuah instrumen tes yang terdiri dari dua bagian. Bagian pertama berisi pertanyaan untuk mengukur atribut responden. Bagian kedua berisi 40 butir pernyataan yang benar atau salah untuk mengukur pengetahuan kedua kelompok petani itu, tentang berbagai aspek beternak domba, sebelum dan sesudah didedahkan pada buku pedoman bergambar tentang cara beternak domba itu.

\section{Uji Coba Instrumen Tes}

Instrumen yang digunakan untuk mengukur pengetahuan para petani tentang berbagai aspek cara beternak domba itu telah diuji coba terlebih dahulu untuk menentukan kesesuaiannya. Uji coba ini dilakukan pada tahap awal kegiatan lapangan penelitian pengembangan sistem produksi ternak domba, di salah satu desa di Majalengka. Uji coba ini melibatkan sepuluh orang petani kerjasama. Seorang penyuluh yang telah dikenal baik oleh para petani kerjasama, membantu peneliti melakukan uji coba itu. Penyuluh tersebut menjelaskan maksud uji coba tersebut dan meminta para petani itu untuk memberikan respon pada seluruh butir instrumen yang dibacakan itu. Respon dan komentar penyuluh dan para petani itu digunakan untuk memperbaiki kalimat-kalimat yang terdapat pada instrument tersebut.

\section{Pengumpulan Data}

Studi ini dilakukan pada minggu ketiga bulan Maret tahun 2003, menjelang introduksi domba Garut di kedua desa tersebut di atas. Kedua kelompok petani dari Desa 
Palasari dan Sukamulya, Kecamatan Ujung Jaya, Kabupaten Sumedang itu diundang untuk mengikuti pelatihan di ruang serbaguna Desa Ujung Jaya, pada tangal 23 Maret 2003. Sebelum acara dimulai, para petani itu diberi sarapan ringan berupa kopi dan kue-kue. Sesi riset ini berlangsung selama satu jam pada pagi hari tersebut. Setiap petani mendapat tempat duduk pada sebuah kursi, yang disusun mengikuti bentuk oval yang menghadap ke layar, instrumen tes, ballpen dan alas tulis portable, untuk membantu yang bersangkutan menuliskan responnya pada alat ukur itu.

Suasana pagi yang masih sejuk dan tenang di sekitar kantor Desa Ujung Jaya itu dan para petani yang masih segar, memungkinkan mereka mengikuti sesi riset dan pelatihan itu dengan tenang dan dapat berkonsentrasi dengan baik pada sesi pagi hari itu.

Sebelum pengumpulan data dimulai, penyuluh menjelaskan terlebih dahulu maksud pertemuan tersebut dan memberi petunjuk tentang cara mengisi jawaban pada pernyataan-pernyataan yang diajukan. Setelah itu pretes dilakukan. Untuk memperlancar pretes, penyuluh membacakan setiap butir pernyataan dan memberi kesempatan kepada para petani itu untuk memilih jawaban yang benar.

Setelah selesai pretes, para petani itu segera diminta untuk membaca buku pedoman bergambar tentang cara beternak domba itu selama 25 menit. Segera setelah waktu membaca itu usai, para petani itu diminta untuk menutup dan menyimpan buku tersebut. Kemudian, dilakukan postes dengan bimbingan penyuluh.

Jumlah waktu yang digunakan untuk seluruh aktivitas itu mencapai sekitar 60 menit. Lima menit pertama digunakan untuk pengantar dan penjelasan, kemudian 25 menit untuk membaca buku pedoman bergambar tentang beternak domba dan masing-masing 15 menit untuk pretes dan postes.

\section{Analisis Data}

Pertama, data atribut para petani dianalisis dengan prosedur statistik deskriptif untuk menentukan rata-ratanya. Kedua, data pretes dan postes dianalisis secara bersamasama, dengan memakai Student t-Test, Paired Two sample for Means Procedure (Hopkins dan Glass, 1978, h. 233-234). Ketiga, data tambahan pengetahuan kedua kelompok petani itu dianalisis dengan menggunakan prosedur statistik t-Test: Two Sample Assuming Unequal Variances (Hopkins dan Glass, 1978, h. 251-252), dan keempat data atribut reponden itu kemudian dikorelasikan dengan data tambahan pengetahuan mereka.

\section{Hasil dan Diskusi}

$\underline{\text { Hasil }}$

1. Pengaruh Buku Pedoman Beternak Domba Bergambar pada Pengetahuan Petani.

Pengaruh pendedahan buku pedoman beternak domba bergambar pada pengetahuan petani tentang cara beternak domba dapat dilihat pada Tabel 2 .

Tabel 2 menunjukkan bahwa rata-rata skor pretes dan postes tentang cara beternak domba milik kedua kelompok petani itu tidak berbeda nyata. Hal ini ditunjukkan oleh nilai $t$ hitung sebesar 0,13 yang lebih kecil dari pada t Tabel, pada taraf nyata 0,05 . Hal ini berarti bahwa pengetahuan kedua kelompok petani itu tentang cara beternak domba sebelum dan sesudah membaca buku pedoman beternak domba bergambar tidak berbeda nyata.

2. Pengaruh Membaca Buku Pedoman Beternak Domba Bergambar pada Tambahan Pengetahuan Petani tentang Cara Beternak Domba

Hasil penelitian tentang skor tambahan pengetahuan tentang cara beternak domba yang didapat oleh para petani tepi hutan yang dilibatkan dalam penelitian ini dapat dilihat pada Tabel 3. 
Tabel 2. Skor Pretes dan Postes Para Petani Miskin di Desa Tepi Hutan Palasari dan Sukamulya, Kecamatan Ujung Jaya Kabupaten Sumedang tentang Cara Beternak Domba

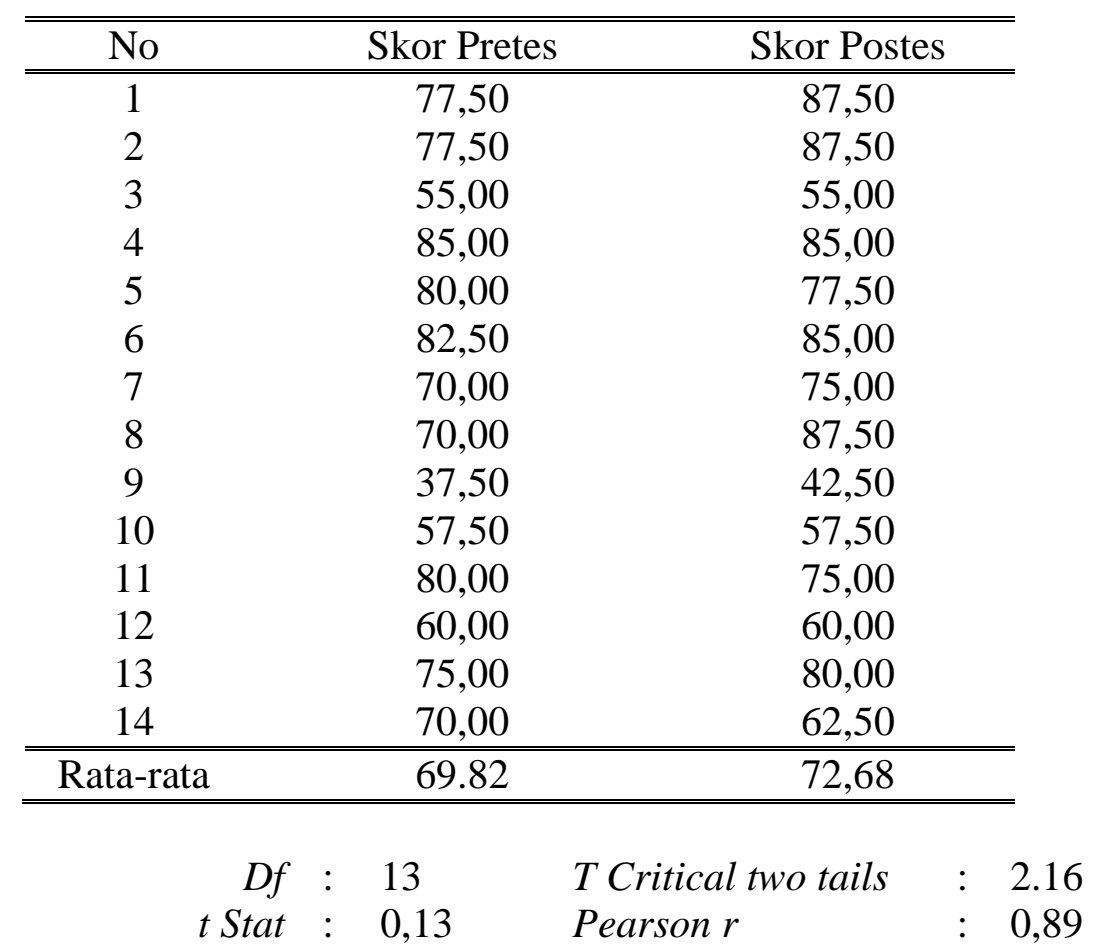

Tabel 3. Skor Tambahan Pengetahuan Petani tentang Cara Beternak Domba

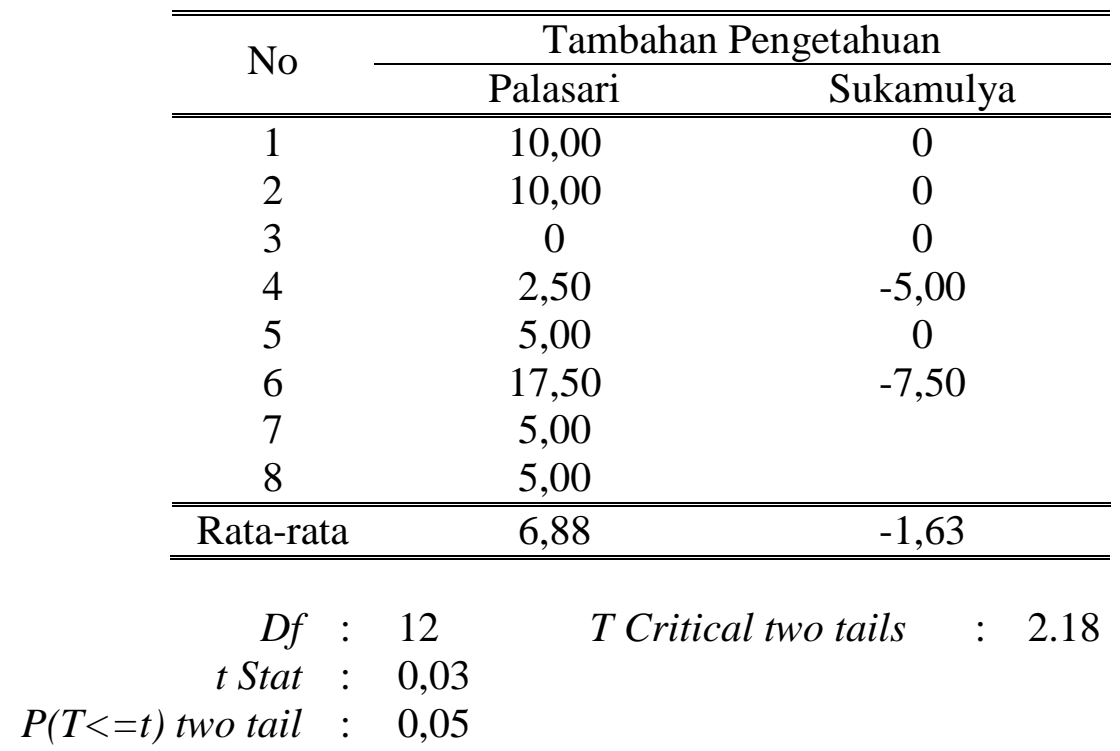

Tabel 3 di atas menunjukkan bahwa tidak seluruh petani yang dilibatkan dalam penelitian ini mengembalikan instrumen pretes maupun postes yang telah mereka isi. Hal ini mengakibatkan perbedaan jumlah responden dari kedua desa itu. Selanjutnya, 
Tabel 3 menampilkan rata-rata skor peningkatan pengetahuan yang dicapai oleh para petani di Desa Palasari dan Sukamulya, secara berturut-turut ialah 6,88 dan-1,63.

Setelah diuji dengan t-test ternyata kedua skor rata-rata tambahan pengetahuan ini tidak berbeda nyata.
3. Hubungan Tiga Karakeristik Petani Tepi Hutan dengan Tambahan Pengetahuan yang Mereka Peroleh

Hasil penelitian tentang hubungan tiga karakteristik petani tepi hutan yang dilibatkan dalam penelitian ini, yaitu: umur, pendidikan dan jumlah tahun setelah lulus dari pendidikan

Tabel 4. Hubungan Tiga Karakteristik Petani Tepi Hutan dengan Tambahan Pengetahuan yang Mereka Peroleh

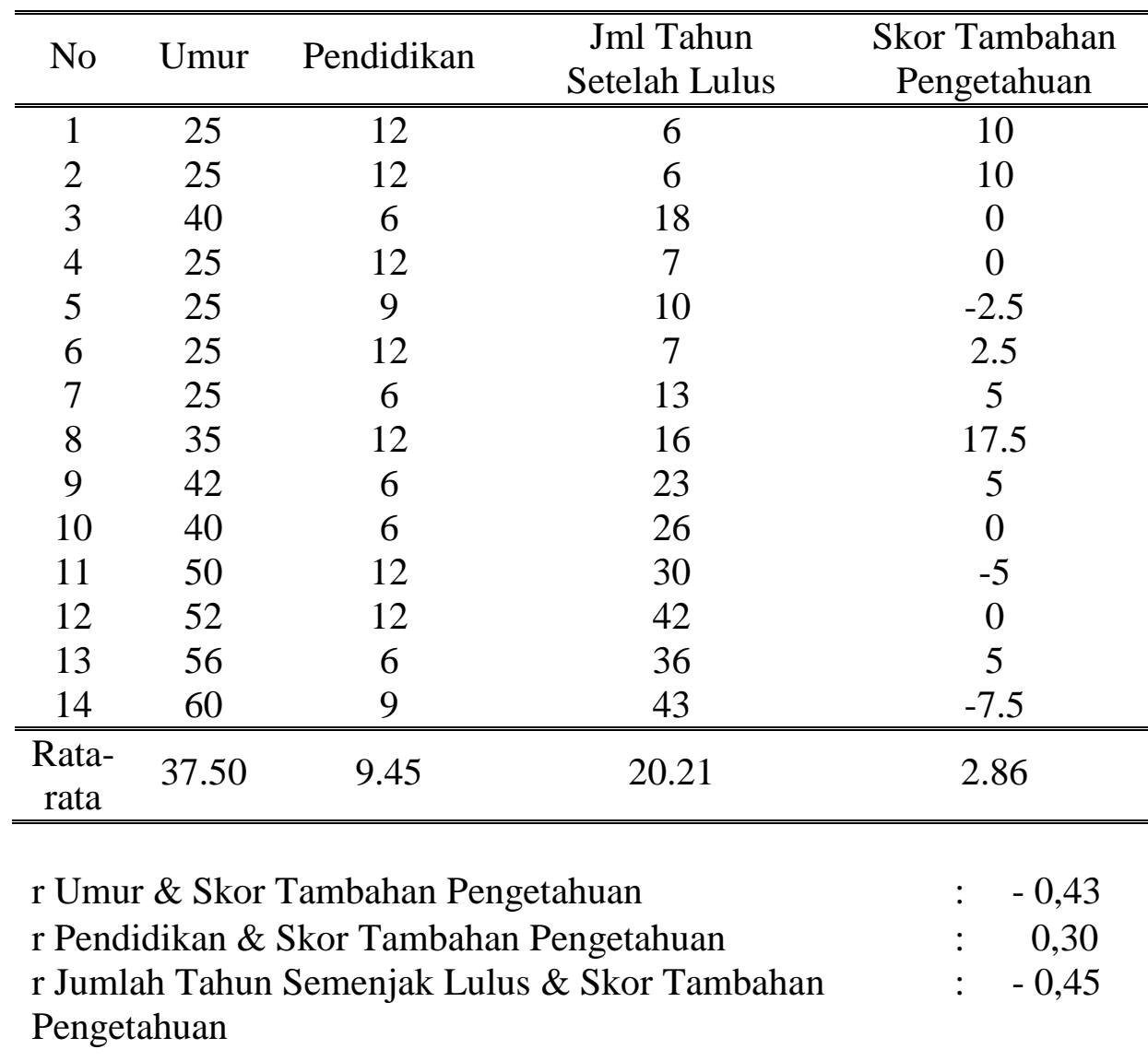

Tabel 4 di atas menunjukkan bahwa intensitas korelasi antara umur responden dengan skor tambahan pengetahuan yang mereka peroleh ialah sebesar $-0,43$, sedangkan koefisien korelasi antara pendidikan responden dengan skor tambahan pengetahuan mereka ialah 0,30 dan koefisien korelasi antara jumlah tahun semenjak kelulusan responden dengan skor terakhir, dengan skor tambahan pengetahuan yang mereka capai dapat dilihat pada Tabel 4 berikut ini.

Tambahan pengetahuan yang mereka peroleh ialah $-0,45$. Ketiga koefisien korelasi ini rendah dan tidak nyata alfa 0,05 . Namun tidak bisa diabaikan.

Hal ini berarti bahwa semakin tua responden, maka semakin kecil skor tambahan pengetahuan yang mereka peroleh. Hal yang serupa terjadi pada jumlah tahun semenjak 
responden lulus. Semakin besar peubah ini, maka semakin kecil pula skor tambahan pengetahuan yang mereka peroleh. Sementara itu, pendidikan responden berkorelasi positif dengan skor tambahan pengetahuan yang mereka peroleh. Jadi, semakin tinggi pendidikan responden maka semakin tinggi pula skor tambahan pengetahuan yang mereka peroleh.

\section{Diskusi}

Selisih skor postes dari pretes atau tambahan pengetahuan yang didapat oleh para petani tepi hutan yang dilibatkan dalam penelitian ini, tidak cukup besar untuk menimbulkan perbedaan yang nyata di antara kedua macam skor tes tersebut secara statistik. Rata-rata selisih skor postes dan pretes hanyalah 2,86 .

Insiden ini ditunjukkan oleh sejumlah skor postes yang tidak bertambah atau lebih kecil dari skor pretes. Ini menimbulkan pertanyaan: "Mengapa skor itu berkurang atau tidak bertambah?" Padahal pendedahan buku pedoman bergambar itu, justru bertujuan untuk menimbulkan perbedaan dalam tambahan pengetahuan.

Hasil yang diperoleh menunjukkan ada perbedaan tersebut. Namun derajatnya masih kurang besar untuk nyata secara statistik. Tabel 4 menunjukkan bahwa ada empat skor pretes dan postes yang sama. Kemudian, ada skor postes yang lebih kecil dari skor pretes. Sedangkan kenaikan skor postes, tidaklah besar. Ketiga hal inilah yang menyebabkan perbedaan skor pretes dan postes itu tidak nyata.

Adapun hal-hal lain yang dapat menjelaskan fenomena ini ialah besaran koefisien korelasi Pearson antara peubah umur dan jumlah tahun semenjak kelulusan dari sekolah. Kedua peubah ini berkorelasi negatif dengan skor tambahan pengetahuan para petani itu. Semakin lanjut usia responden maka semakin terbatas kemampuannya untuk memahami buku pedoman beternak domba itu. Pesan visual dan tertulis yang terdapat pada setiap bingkai buku pedoman beternak domba bergambar itu, sulit mereka cerna dan integrasikan untuk menimbulkan pemahaman yang lebih baik.

Hal ini terjadi karena gambar dan teks diproses dan disimpan di dua tempat yang berbeda dalam otak manusia. Penelitian menunjukkan bahwa orang umumnya membaca dengan belahan otak kiri (Benson dalam Klinger, 2000, 5). Dalam hubungan ini, gambar lebih mudah diingat dari pada teks (Park dan Gabrielli dalam Klinger, 2000, 6). Namun gambar dapat mengalihkan perhatian orang dari teks (Klinger, 2000, 14).

Persaingan gambar dan teks dalam benak petani, menyulitkan mereka untuk mengintegrasikan dan mengingat kembali pesan-pesan visual dan tekstual itu, ketika dihadapkan pada pilihan benar atau salah pada postes. Kesulitan inilah yang mengurangi kemampuan mereka pada postes. Hal ini ditunjukkan oleh skor postes yang relatif tidak berubah, lebih kecil atau meningkat sedikit dari skor pretes.

Demikian juga halnya dengan lamanya waktu dari kelulusan sampai ke saat penelitian. Semakin besar peubah tersebut, maka semakin terbatas pula kemampuan mereka mencerna dan mengintegrasikan unsur visual dan tertulis pada setiap bingkai buku pedoman itu, untuk menjadi suatu pemahaman. Ini terjadi karena visual memory skills maupun textual memory skills mereka kurang berkembang, karena jarang dipakai.

Hal lain yang juga dapat menjelaskan fenomena ini, ialah lama waktu baca dan bahasa yang digunakan pada instrumen pengukuran dan buku pedoman itu. Waktu baca yang diberikan hanyalah 25 menit. Tampaknya terlalu singkat. Ini dikukuhkan oleh penelitian sejenis di Desa Ciomas dan Kawung Girang di Majalengka. Hasil penelitian ini menunjukan bahwa tambahan waktu baca, meningkatkan tambahan pengetahuan para petani itu tentang cara beternak domba secara nyata (Jahi, 2001).

Kemudian, bahasa yang digunakan dalam buku pedoman beternak domba 
bergambar itu ialah bahasa Indonesia. Mungkin mereka kurang menguasai bahasa nasional itu dengan baik, karena jarang memakainya dalam kehidupan sehari-hari. Penyederhanaan atau penerjemahan buku tersebut kedalam bahasa Sunda yang selalu mereka pakai mungkin akan memperbaiki kinerja mereka.

\section{Kesimpulan}

Hasil penelitian dan diskusi yang telah dipaparkan di atas mengarah pada butir-butir kesimpulan berikut ini:

1. Penggunaan buku bergambar tentang cara beternak domba dapat meningkatkan kapasitas petani miskin di dua desa tepi hutan di kecamatan Ujung Jaya, kabupaten Sumedang.

2. Pengaruh buku bergambar tersebut pada peningkatan pengetahuan para petani kerjasama di dua desa di kecamatan Ujung Jaya, kabupaten Sumedang itu masih terbatas.

3. Pendidikan para petani kerjasama itu berhubungan secara positif dengan tambahan pengetahuan tentang cara beternak domba yang mereka peroleh.

4. Umur dan jumlah tahun semenjak kelulusan para petani kerjasama itu dari sekolah hubungannya negatif dengan tambahan pengetahuan tentang cara beternak domba yang mereka peroleh.

\section{Rujukan}

Amri Jahi. "Promoting Small Ruminant Production Systems with Small Farmers and Landless Peasants in Selected Villages, District of Majalengka, West Java." Research Report. Bogor: Faculty of Animal Husbandry, Institut Pertanian Bogor and International Development Research Centre, 1989. (Photocopied).
Amri Jahi. "Pengaruh Pendedahan Buku Bergambar tentang Cara Memelihara Domba pada Peningkatan Pengetahuan Peternak Domba Garut di Desa Ciomas dan Kawung Girang, Kabupaten Majalengka, Jawa Barat." Media Peternakan 24 (Desember 2001): 33-38.

Campbell, Donald T. and Julian C. Stanley. Experimental and Quasi Experimental Designs for Research. Chicago: Rand MacNally College Publishing Company, 1966.

Community Development Resource Association (CDRA). "Capacity Building: Myth or Reality?" Didapat dari

http://www.cdra.org.za/AnnualRep/1995 \%20-\%20Capacity\%20Building\%20\%Myth\%20or\%20Reality\%20\%20From\%20the\%2020CDR; internet; diakses pada 4 September 2005.

Hopkins, Kenneth D. and Gene V. Glass. Basic Statistics for the Behavioral Sciences. Englewood, Cliffs, New Jersey: Prentice Hall, Inc., 1978.

Klinger, William. "Effects of Picture on Memory and Learning. " Didapat dari htpp:

//www2.ice.usp.sc.jp/wklinger/QA/articl es/kiyou2000/kiyou2000.html; internet; diakses pada 26 Juli 2005.

Sri Roso Satmoko. "Pengaruh Tokoh Cerita dan Warna Gambar Buku Komik pada Peningkatan Pengetahuan Peternak tentang Tata Laksana Beternak Domba di Desa Kulur, Kecamatan Majalengka, Kabupaten Majalengka." Tesis Magister Sains. Program Pascasarjana, Institut Pertanian Bogor, 1994.

Tim Peneliti Pengembangan Sistem Produksi Ruminansia Kecil. "Pedoman Beternak Domba." Bogor: Fakultas Peternakan, Institut Pertanian Bogor, 1999. (Fotokopi). 